\title{
Identifying change agent types and its implications for corporate sustainability integration based on worldviews and contextual factors
}

\section{A R T I C L E I N F O}

\section{Article history:}

Received 10 May 2018

Received in revised form

17 April 2019

Accepted 21 April 2019

Available online 29 April 2019

\section{Keywords:}

Change agents

Worldviews

Corporate sustainability integration

Context factors

\begin{abstract}
A B S T R A C T
Change agents for Corporate Sustainability (CS) play an important role for companies when integrating CS into their business activities. While change agents can be differentiated by their worldviews, little is known about the contextual factors influencing their success in supporting CS integration. By proposing and illustrating an analytical model based on contextual factors of CS integration and change agents' worldviews, this paper contributes to the understanding of their influence on CS integration. Through a case study we find that change agents show a worldview profile rather than a specific worldview and that whether a worldview is supportive for CS integration depends on the specific context. We conclude that the analytical model contributes to the understanding of the individual and group level of CS integration. When discussed with company representatives, the outcomes of the application of the model could contribute to improve the identification of key individuals to support CS integration activities.
\end{abstract}

(c) 2019 Elsevier Ltd. All rights reserved.

\section{Introduction}

Corporate Sustainability (CS) plays a vital role in ensuring organisations' positive impact on the environment and society (Gibson and Birkinshaw, 2004; Lozano, 2012; Stubbs and Cocklin, 2008). This implies that companies need to integrate economic, social and environmental issues (i.e. triple issue focus) (Maas et al., 2016) into their business activities. CS integration requires a revision and adjustment of the allocation to and the coordination of people, resources and functions to organisational tasks, and is focused on the dynamic capabilities that enable companies to satisfy current demands while simultaneously being prepared for tomorrow's developments (Gibson and Birkinshaw, 2004). The resulting necessity for interventions in the organisation aimed at CS integration requires the application of a different combination of corporate processes (i.e. developing the structure of the organisation), performance measurement, and reward systems (i.e. ensure

\footnotetext{
* Corresponding author.

E-mail addresses: J.v.d.Berg@tue.nl (J. van den Berg), michiel.zijp@rivm.nl (M.C. Zijp),w.j.v.vermeulen@uu.nl (W.J.V.Vermeulen), s.witjes@fm.ru.nl (S.Witjes).
}

continuous improvement of the organisation) (Maas et al., 2016), but also a change in leadership, culture, and people's attitudes or values (i.e. the socio-cultural elements of the organisation) (Epstein and Buhovac, 2010).

To support interventions in the organisational system, companies have been developing numerous mechanisms (Visser and Crane, 2010; Witjes et al., 2018) whose application could affect the company's physical or social dynamics (Schein, 2015). The use of these integration mechanisms entails determining and applying objects, activities or verbal expressions (Witjes et al., 2018), leading to adjustments to processes and products, revision of communication strategies, and adaptation of value and knowledge systems (Azapagic and Perdan, 2005; Epstein and Buhovac, 2010; Siebenhüner and Arnold, 2007). CS specifically needs to be integrated into the organisational culture (Baumgartner, 2009; Linnenluecke and Griffiths, 2010), implying an important role for leadership (Benn et al., 2006; Doppelt, 2009; Eisenbach et al., 1999; Hatch and Cunliffe, 2013). Change agents play an important role in the process of CS integration by leading the change effort and coordinating the use of integration mechanisms aimed at the integration of CS (Kitzmueller and Shimshack, 2012; Witjes et al., 2018).

Whereas research on CS integration has focused mainly on the 
organisational level (Schein, 2014; Visser and Crane, 2010), the importance of the individual level for the success of CS integration is often overlooked (Arrata et al., 2007). While the concept of CS and the different strategies, models or methods to reach it have been highlighted extensively in research (Dyllick and Hockerts, 2002; Lozano et al., 2015; Salzmann et al., 2005; Van Marrewijk, 2003), how to arrive at their successful implementation by organisational members has received little attention. This article contributes to the literature by premising that successful CS integration can only be accomplished by the initiation and management of this process by change agents within the organisation. The idea of change agents for CS is not new (see Hesselbarth and Schaltegger, 2014; Weerts et al., 2018). However, some existing work has focused on CS integration approaches utilized by change agents with official leading or managing roles (Weerts et al., 2018). Others do recognize the change agent potential of other individuals but solely focus on their competencies (e.g. analytical skills (Hesselbarth and Schaltegger, 2014). There is a need for a more holistic understanding of the contribution of change agents to CS integration (Epstein and Buhovac, 2010; Miller and Serafeim, 2014). This article contributes to the literature by asserting that such an understanding arises from (i) expanding the range of whom to consider as change agents and (ii) expanding the way we characterize them. One way to gain a holistic understanding of change agents is through their worldviews. However, as individuals do not act in isolation but are part of a context, the understanding of change agents requires the study of worldviews in combination with the context in which the change agent is situated. Our study thus adds insights from a psychological point of view. It provides a model to assess the 'change agent potential' of different individuals given the match between the change agent's worldview and the context in which the change agent operates. Indeed, little is known about how worldviews (Hunter et al., 2011; Schein, 2015) and contextual factors (Armenakis and Bedeian, 1999; Walker et al., 2007) may affect change agents in contributing to CS integration. Therefore, our main research question is as follows:

What is the influence of the combination of change agent worldviews and context factors in the process of CS integration?

The aim of this paper is to propose and illustrate an analytical model to investigate change agents' influence on CS integration and thereby to contribute to the understanding of change agents and their contribution to CS integration. In section 2, a literature review and discussion on CS integration, the concept of change agent, worldviews, and contextual factors leads to the proposal of an analytical model. Section 3 explains the methods applied and introduces the case study. Subsequently, the case study results are used for the illustration of the framework discussed in section 4 . This is followed by an analysis of these results in section 5 . This paper finishes with a discussion including the lessons drawn from the case study, its implications and limitations and suggestions for future research in section 6 .

\section{Change agents intervening for corporate sustainability integration into the organisational system}

\subsection{Corporate sustainability integration}

To integrate CS into an organisational system companies have been developing numerous integrating mechanisms, which are activities especially applied by managers and change agents (UhlBien and Arena, 2018) in order to create the most favourable conditions to attain their objectives, while at the same time ensuring an effective and efficient use of their resources (Hatch and Cunliffe,
2013; Hill and Jones, 2011). Integration mechanisms have been discussed by scholars from organisation theory and strategic management fields (Burgers et al., 2009; Karlsson et al., 2010; O'Reilly and Tushman, 2013). Integration mechanisms include hierarchy, cross-functional teams, permanent teams, task forces, direct contact or communication between departments or managers and integrating roles or liaison roles (Hatch and Cunliffe, 2013; Hill and Jones, 2011). We argue that for the process of CS integration, an important role can be assigned to permanent teams, task forces and integrating roles. Task forces are ad hoc committees and function on a temporary basis; once the problems are solved, members return to their normal roles. To deal with reoccurring problems effectively, permanent teams can be established (Dam et al., 2011). It can be argued that some CS integration processes require a task force (e.g. moving from a work environment based on paper use towards one where people work digitally), and others permanent team (e.g. working with lean principles in which is aimed at continuous improvement in organisational processes). Within these teams and task forces, specific people take the lead, and communicate and coordinate the activities between the different actors involved, thereby taking additional integrating or liaison roles (Hatch and Cunliffe, 2013; Hill and Jones, 2011). As the success of such teams or task forces seems to rely on those specific people, and integrating CS into an organisation can be viewed as something that requires change, we attribute a certain level of agency to these individuals. For the purpose of this research, we therefore define these people as change agents.

\subsection{Change agents}

Change agents can be defined as individuals either external or internal to the organisation who assist in managing (Herron and Hicks, 2008), triggering or promoting the change effort (Strudler and Gall, 1988). According to (Van der Heijden, Cramer and Driessen, 2012), change agents can be senior managers or organisational members who have been specifically assigned to manage the change process. However, more often than not, we only see a partial image of change agents for CS integration, since it is often assumed that only managers or formal leaders can fulfil the role of change agent. But, as Visser and Crane (2010) put it, "Not all sustainability champions are sustainability managers, and not all sustainability managers are sustainability champions". Thus, CS can be promoted by individuals from all hierarchical layers, with or without an official level of authority (Hesselbarth and Schaltegger, 2014). However, solely promoting CS does not suffice to describe the merit of these individuals, as the term merely seems to imply that people support a certain cause, in this case CS. Arguably, the success of CS does not rely on championship alone, it requires more. Therefore, we prefer the use of the term change agent as opposed to synonyms such as champion (Lozano, 2006), as agents have, next to the actual intention of doing something, a certain level of power which enables them to actually put this intention into action (Giddens, 1984), be it the senior manager of the organisation or be it the employee on the shop floor.

\subsubsection{Change agent worldviews}

So, to understand the contribution of change agents to CS integration we need to adopt a more comprehensive way of looking at individuals. One way of doing this is by looking at their worldviews, which are comprised of both personality related aspects as well as how these actually manifest themselves in certain behaviours. Worldviews of change agents for CS can be researched from a developmental psychology frame (Boiral et al., 2009; Brown, 2011; Divecha and Brown, 2013) and range from pre-conventional towards conventional and finally, post-conventional (Lynam, 2012). 
As a change agent moves from one worldview towards the next, his or her worldview develops from simple to complex, from static to dynamic and from egocentric to socio-centric to world-centric (Cook-Greuter, 2004). Each later worldview reflects an increased capacity to function in a complex and changing environment (McEwen and Schmidt, 2007). Word views reflect the change agent's level of complexity, the extent to which he or she can deal with different situations and the extent to which he or she is personally engaged (Beck and Cowan, 1996). Thus, worldviews comprise more than just simple listing of personality characteristics and related actions, it entails a broad spectrum of cognitive and behavioural states, encompassing the individual's entire being.

Seven worldviews have been defined (Rooke and Torbert, 2005) that can be used to analyse the different approaches to change agency: 1) the Opportunist (pre-conventional), 2) the Diplomat, 3) the Expert, 4) the Achiever (all conventional), 5) the Individualist, 6) the Strategist and, 7) the Alchemist (all post-conventional). With multiple authors discussing these worldviews (e.g. (Boiral et al., 2009; Brown, 2012, 2011; Cook-Greuter, 2004; Divecha and Brown, 2013; Lynam, 2012; McEwen and Schmidt, 2007; Schein, 2014; Vincent, 2014; Vincent et al., 2015, 2013), the following compilation (see Table 1) presents the typical personality characteristics and capabilities (i.e. column A with typical manifestations) and types of behaviour and activities reflected by each worldview (implications for sustainability leadership (i.e. column B), strengths (i.e. column C) and weaknesses (i.e. column D)) which serves as the source for the operationalization in Section 4.

When considering the worldview typology of Table 1 , several different personality characteristics and capabilities as well as behaviours and activities can be allocated to each worldview. Considering their characteristics, change agents with (pre-)conventional worldviews each reflect a desire for some form of control (Boiral et al., 2009; Rooke and Torbert, 2005). In general, the Opportunists, Diplomats and Eindxperts are not capable of handling conflicts easily (Boiral et al., 2009) and are not open to feedback (Cook-Greuter, 2004; Lynam, 2012). As reflected by their behaviour, these change agents have a limited vision on or understanding of sustainability (e.g. Boiral et al., 2009; Brown, 2011; Lynam, 2012). We contend that such qualities likely result in an incapability to integrate sustainability issues into the organisational system. In turn, Achiever change agents find themselves in between the more conventional and post-conventional worldviews. For example, their behaviour does reflect the recognition of the importance of sustainability (Lynam, 2012; Schein, 2014), setting them apart from the (pre-)conventionalists, but their personality is not characterized by a high level of self-awareness as holds for post-conventional change agents (Vincent et al., 2015, 2013).

In contrast to those with (pre-)conventional worldviews, change agents with post-conventional worldviews are better capable of dealing with conflicts (Boiral et al., 2009; Rooke and Torbert, 2005) and are more open to feedback (Cook-Greuter, 2004). They are also increasingly tolerant towards ambiguity and uncertainty (Brown, 2012; McEwen and Schmidt, 2007; Vincent et al., 2015), indicating a decreasing desire for control. Their behaviours and activities reflect a long-term vision (Baron and Cayer, 2011; Lynam, 2012; Schein, 2015, 2014), a focus on the wider context of sustainability (Lynam, 2012; Schein, 2014) and its true integration in the organisation (Boiral et al., 2009; Brown, 2011; Lynam, 2012). Therefore, change agents seem to be most effective in their roles when they display a post-conventional worldview (Boiral et al., 2009; Brown, 2012; Rooke and Torbert, 2005).

\subsubsection{Context factors influencing change agents impact on} corporate sustainability integration

The effectiveness of a change agent does not only depend on the worldview, it is also supported or mitigated by context factors (Witjes et al., 2017a). Context factors can be divided into content factors, and internal and external factors (e.g. Armenakis and Bedeian, 1999; Walker et al., 2007).

Content factors refer to the type of change that CS integration represents, thus either incremental or radical or a combination (Walker et al., 2007). Radical change is often episodic, disruptive, planned - there was an intention to pursue the change prior to the change - and top-down implemented, whereas incremental change is often emergent, continuous, bottom-up implemented and adaptive (Petersen et al., 2004) and alters the organisation in a slow step-by-step movement (Walker et al., 2007). CS integration can represent a radical change, for example for companies which have not yet dealt with CS. Naturally, once they start implementing CS related strategies or alterations to the organisation, it poses a disruption to the status quo. For this reason, it is almost always pursued top down, as organisations usually do not accept the status quo being threatened from the bottom up. It can also represent an incremental change, for example in case of a company where elements of CS have already been pursued earlier and there is simply a continuation of the implementation process. In such as case, bottom up implementation is possible as the change does not pose a threat anymore and the proverbial green light already has been given earlier on.

Internal factors relate to the change process itself and include setting relevant and realistic objectives (Stelzer and Mellis, 1998), communication, (Fernandez and Rainey, 2006), involving organisational members (Armenakis and Bedeian, 1999; Fernandez and Rainey, 2006; Stelzer and Mellis, 1998), collaboration between teams (Stelzer and Mellis, 1998), planning and controlling, effective measuring and continuous maintenance, support and improvement (Stelzer and Mellis, 1998) and monitoring and evaluating (Fernandez and Rainey, 2006). Other internal factors include matching the change to the strengths and weaknesses of different teams and departments and reorganising the roles and responsibilities with respect to the new organisational structure (Stelzer and Mellis, 1998). Internal factors thus indicate the extent to which the change agent and other organisational members concerned with the change process take actions that are aimed at increasing the level of success.

External factors can be factors external to the change process or external to the organisation. Factors external to the change process include the presence or lack of management support (Fernandez and Rainey, 2006; Herron and Hicks, 2008; Walker et al., 2007; Stelzer and Mellis, 1998), resources and their redirection or redeployment towards new activities (Fernandez and Rainey, 2006), levels of expertise, presence of specialized knowledge and excess, underutilized resources (Walker et al., 2007), the change history of the organisation (has the organisation experienced the same type of change before?) and whether the change for CS is consistent with the identity and image of the organisation (Armenakis and Bedeian, 1999). Factors external to the organisation include competition, lack of government regulations, changes in legislation or technology (Walker et al., 2007) and the presence or lack of support of key external stakeholders (Fernandez and Rainey, 2006). Such external factors are important for the change agent and others to take into consideration, however, they cannot directly influence these factors themselves.

\subsection{Proposing an analytical model to assess change agents' potential for successful CS integration}

Change agents play a key role in CS integration. The extent of their influence depends both on their worldview as on the contextual factors. Based on the literature in this section, we 
Table 1

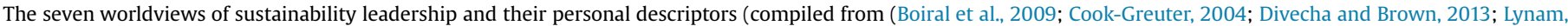

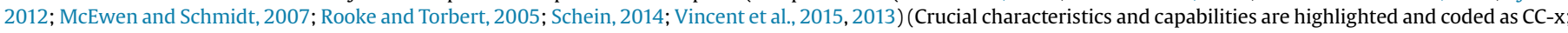
and the behaviours and activities as BA-y to be used in the analysis as described in section 4.2.1 and 4.2.2 (see also Tables 4 and 5)).

\begin{tabular}{|c|c|c|c|c|c|}
\hline Worldview & & A. Typical manifestations & $\begin{array}{l}\text { B. Implications for } \\
\text { sustainability leadership }\end{array}$ & C. Strengths & D. Weaknesses \\
\hline Pre-conventional & $\begin{array}{l}\text { A1 Opportunist } \\
\text { (Coercive } \\
\text { power) }\end{array}$ & $\begin{array}{l}\text { A1. Impulsive (CC-1), demanding (CC- } \\
\text { 2), dependent (Vincent et al., 2015), } \\
\text { externalizing blame, (Divecha and } \\
\text { Brown, 2013; Vincent et al., 2015), } \\
\text { focus on personal wins, the world and } \\
\text { other people are considered } \\
\text { opportunities to be exploited (Rooke } \\
\text { and Torbert, 2005), rejects feedback (is } \\
\text { seen as an attack) (Cook-Greuter, 2004), }\end{array}$ & $\begin{array}{l}\text { B1. Environment is seen as a } \\
\text { collection of resources for } \\
\text { exploitation (Boiral et al., 2009), } \\
\text { focus on self (Brown, 2011; } \\
\text { Divecha and Brown, 2013), few } \\
\text { and short term measures (BA- } \\
\text { 24), only sensitive to } \\
\text { sustainability issues when it } \\
\text { affects him personally (BA-25) }\end{array}$ & $\begin{array}{l}\text { C1. Quick to respond to } \\
\text { sustainability issues (Boiral } \\
\text { et al., 2009; Brown, 2011), } \\
\text { seizing sustainability } \\
\text { opportunities (emergencies } \\
\text { and sales) (Rooke and } \\
\text { Torbert, 2005; Boiral et al., } \\
\text { 2009; Brown, 2011) }\end{array}$ & $\begin{array}{l}\text { D1. Limited understanding } \\
\text { of what sustainability is } \\
\text { (Brown, 2011), no regard } \\
\text { for sustainability impacts } \\
\text { (Boiral et al., 2009; Brown, } \\
\text { 2011), few people want to } \\
\text { follow them in the long } \\
\text { term (Rooke and Torbert, } \\
\text { 2005) }\end{array}$ \\
\hline
\end{tabular}

Conventional A Diplomat (Persuasive power)

A3 Expert (Authoritative power)

A4 Achiever (Coordinating power)
Post-conventional A5 Individualist (Confronting power) (by means of a threat by perception of control (CC-9)(Rooke (Boiral et al., 2009; Brown, and Torbert, 2005)

2011)

A2. Conventional (CC-4), rule-bound B2. Focus on expected (Vincent et al., 2015), need for belonging (CC-3) (Rooke and Torbert, 2005; McEwen and Schmidt, 2007; Brown, 2011; Lynam, 2012; Vincent et al., 2015), avoids conflict (Rooke and Torbert, 2005; McEwen and Schmidt, 2007; Brown, 2011; Lynam, 2012; Schein, 2014), is loyal to a certain grou (McEwen and Schmidt, 2007; Lynam, 2012; Schein, 2014), focus on control (CC-9) of own behaviour instead of external events/people, overly polite and friendly, has difficulties giving challenging feedback (Rooke and Torbert, 2005), feedback is received as disapproval (Cook-Greuter, 2004; Lynam, 2012)

A3. Desires to stand out, wants to be unique (CC-6) (Divecha and Brown, 2013; Vincent et al., 2013), a perfectionist (CC-5) (McEwen and Schmidt, 2007; Brown, 2011; Divecha and Brown, 2013), has some selfawareness and is appreciative of multiple possibilities, self-critical, emerging awareness of inner feelings of self and others (Vincent et al., 2015), thinks he is always right (Rooke and Torbert, 2005), takes feedback personally (Cook-Greuter, 2004), and does not accept feedback from people who are not considered experts in the field (Cook-Greuter, 2004; Lynam, 2012), exercises control (CC-9) by perfecting his knowledge (Rooke and Torbert, 2005)

behaviour and approval (BA-

26) (McEwen and Schmidt,

2007; Brown, 2011; Lynam,

2012; Schein, 2014), supports

environmental initiatives out of concern for the organisation's image/appearance (BA-27)

(Boiral et al., 2009; Brown, 2011; Schein, 2014), calms pressures related to sustainability issues within the organisation (Boiral et al., 2009; Brown, 2011), sustainability is considered out of a sense of moral obligation/concerns for security (Lynam, 2012)

B3. Considers sustainability issues from a technical, specialized perspective (BA-29) (Boiral et al., 2009; Brown, 2011; Schein, 2014); Sustainability is a technical issue that requires proven environmental services (Lynam, 2012), pursues continuous improvement, efficiency and perfection (McEwen and Schmidt, 2007; Lynam, 2012), searches for scientific certitude before acting, preference for proven technical approaches (Boiral et al., 2009; Brown, 2011), focuses on compliance with environmental laws (Schein, 2014)

A4. Reflective (CC-8), responsible (CC-7) B4. Integrates sustainability and empathic, perceives broader issues in organisation's complexities and patterns, self-critical, objectives and procedures, is (Vincent et al., 2015), looks beyond concerned with improving personal concerns (Vincent et al., 2013), performance (BA-31) (Boira open to feedback if (Lynam, 2012) or et al., 2009; Brown, 2011); especially when it supports goals recognizes need for (Cook-Greuter, 2004), wants to improve sustainability performance himself (Vincent et al., 2013), values measures (Lynam, 2012; achievements, (Vincent et al., 2015) and Schein, 2014), effectively focuses on results (Lynam, 2012; Schein, 2014)

A5. High sense of personal identity, tolerant towards self and others (CC11)(Vincent et al., 2015), appearing awareness (CC-15) of inner conflicts (CC-21, CC-22) (Divecha and Brown, 2013; Vincent et al., 2013, 2015) and paradoxes (CC-18), values relationship over achievements (CC-10) (Vincent et al., 2015), interested in unique expressions of self and others (McEwen (Boiral et al., 2009; Brown,

\section{C2. Considers regulatory} limitations, reactive attitude with respect to sustainability pressures (Boiral et al., 2009; Brown, 2011), supportive glue on teams, brings people together (Rooke and Torbert, 2005; McEwen and Schmidt, 2007; Brown, 2011; Lynam, 2012)

2011; Lynam, 2012)

\section{D2. Superficial coherence} with external pressures, lack of true revaluation of current practices, statements often contradict actions (BA-28) (Boiral et al., 2009; Brown, 2011), incapable of providing painful feedback or making the hard decisions necessary to improve performance (Rooke and Torbert, 2005)

C3. Development of sustainability knowledge

D3. No clear definition of the concept of

(BA-30), implementation of sustainability (Lynam, sustainability technologies 2012), limited vision on (Boiral et al., 2009; Brown, sustainability, no 2011), good individual integration of sustainability contributor (Rooke and Torbert, 2005; Brown, 2011) issues, does not appreciate collaboration (Boiral et al., 2009; Brown, 2011), no desire or appreciation of emotional intelligence or respect for people with less expertise (Rooke and Torbert, 2005)

C4. Pursues employee involvement (Boiral et al., 2009; Brown, 2011), challenges and supports employees, creates a positive team (Rooke and Torbert, 2005), well suited to managerial work (Rooke and Torbert, 2005; Brown, 2011), action and goal oriented (BA-32) (Brown, 2011) achieves goals through (Brown, 2011)

C5. Personal commitment responsibility to the planet (BA- (BA-34), active 41); nature has intrinsic rights consideration of (BA-42) (Lynam, 2012; Schein, 2014), integrates opposing own and company's behaviour

(Brown, 2011), develops creative and original sustainability solutions (BA-33) suggestions and ideas of others (Boiral et al., 2009; Brown, 2011), stimulates awareness of other worldviews (McEwen and Schmidt, 2007), effective in consulting roles (Rooke and
D4. Lacks critical attitude towards conventions, finds it difficult to challenge current management systems (Boiral et al., 2009; Brown, 2011), does not think outside the box (Rooke and Torbert, 2005)

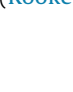

D5. Long and unproductive D5. Long and unproductive
discussions, idealism that may lack logic (Boiral et al., 2009; Brown, 2011), ignoring key processes and people in the organisation (Rooke and Torbert, 2005), ignoring rules when they (BA-35) (Rooke and 
Table 1 (continued)

\begin{tabular}{|c|c|c|c|c|c|}
\hline \multirow{2}{*}{\multicolumn{2}{|c|}{ Worldview }} & A. Typical manifestations & $\begin{array}{l}\text { B. Implications for } \\
\text { sustainability leadership }\end{array}$ & C. Strengths & D. Weaknesses \\
\hline & & $\begin{array}{l}\text { and Schmidt, 2007; Divecha and Brown, } \\
\text { 2013), communicates well with people } \\
\text { who have other action logics (CC-19, } \\
\text { CC-20)(Rooke and Torbert, 2005), } \\
\text { feedback is considered necessary for } \\
\text { self-knowledge (CC-23) (Cook-Greuter, } \\
\text { 2004), }\end{array}$ & $\begin{array}{l}\text { 2011; Lynam, 2012), questions } \\
\text { accepted ideas and underlying } \\
\text { assumptions, development of a } \\
\text { participative approach } \\
\text { requiring employee } \\
\text { involvement (McEwen and } \\
\text { Schmidt, 2007; Boiral et al., } \\
\text { 2009; Brown, 2011), discusses } \\
\text { issues and differences (Brown, } \\
\text { 2011; Lynam, 2012) }\end{array}$ & $\begin{array}{l}\text { Torbert, 2005; Brown, } \\
\text { 2011) }\end{array}$ & $\begin{array}{l}\text { Torbert, 2005; McEwen and } \\
\text { Schmidt, 2007) or adapting } \\
\text { them/creating new rules } \\
\text { (McEwen and Schmidt, } \\
\text { 2007; Lynam, 2012) }\end{array}$ \\
\hline & $\begin{array}{l}\text { A6 Strategist } \\
\text { (Integrative } \\
\text { power) }\end{array}$ & $\begin{array}{l}\text { A6. Highly collaborative (CC-12)(Rooke } \\
\text { and Torbert, 2005), highly self-aware } \\
\text { (CC-15) (Vincent et al., 2013), respects } \\
\text { people (Vincent et al., 2013), } \\
\text { relationships are seen as } \\
\text { interdependent (McEwen and Schmidt, } \\
\text { 2007), tolerates ambiguity ((CC-17) } \\
\text { (Brown, 2012; Vincent et al., 2015), and } \\
\text { paradoxes (CC-18) (Vincent et al., } \\
\text { 2013), recognizes the systemic nature } \\
\text { of relationships (CC-16), able to cope } \\
\text { with (inner) conflicts (CC-22) (Vincent } \\
\text { et al., 2015), feedback is invited for self- } \\
\text { actualisation (CC-23) (Cook-Greuter, } \\
\text { 2004), }\end{array}$ & $\begin{array}{l}\text { B6. Thinks decisions should be } \\
\text { based on greatest good for } \\
\text { humanity (BA-41) and nature } \\
\text { (BA-42) (Lynam, 2012), brings } \\
\text { about transformations on } \\
\text { individual and organisational } \\
\text { level (Brown, 2011), reframes } \\
\text { issues (McEwen and Schmidt, } \\
\text { 2007; Brown, 2011; Lynam, } \\
\text { 2012), challenges existing } \\
\text { assumptions (Rooke and } \\
\text { Torbert, 2005), proposes a pro- } \\
\text { sustainability vision and } \\
\text { culture, interest for global } \\
\text { sustainability issues, strives for } \\
\text { integration of economic, social } \\
\text { and ecologic aspects (Boiral } \\
\text { et al., 2009; Brown, 2011) }\end{array}$ & $\begin{array}{l}\text { C6. Transformational } \\
\text { leadership (Rooke and } \\
\text { Torbert, 2005; Brown, } \\
\text { 2011), true integration of } \\
\text { sustainability, long term } \\
\text { perspective (Boiral et al., } \\
\text { 2009; Brown, 2011), } \\
\text { socially conscious business } \\
\text { ideas carried out in a } \\
\text { collaborative manner, } \\
\text { capable of creating shared } \\
\text { visions among people with } \\
\text { different action logics (BA- } \\
\text { 37), well able to handle } \\
\text { people's resistance to } \\
\text { change (BA-36) (Rooke and } \\
\text { Torbert, 2005) }\end{array}$ & $\begin{array}{l}\text { D6. Approach may seem } \\
\text { impractical and difficult to } \\
\text { understand, risk of } \\
\text { disconnecting with } \\
\text { pressure for short term } \\
\text { gains (Boiral et al., 2009; } \\
\text { Brown, 2011) }\end{array}$ \\
\hline & $\begin{array}{l}\text { A7 Alchemist } \\
\text { (Shamanistic } \\
\text { power) }\end{array}$ & $\begin{array}{l}\text { A7. Charismatic (CC-13) (Rooke and } \\
\text { Torbert, 2005), wise (CC-14), broadly } \\
\text { empathic, highly self-aware (CC-15), } \\
\text { reconciles inner conflicts and integrates } \\
\text { paradoxes (CC-17), understands own } \\
\text { intrinsic nature (Vincent et al., 2015), is } \\
\text { self-reflecting and realizing (self- } \\
\text { actualisation)(CC-22) (Vincent et al., } \\
\text { 2013), starts to see manners of own } \\
\text { thought and language (Vincent et al., } \\
\text { 2013), recognizes limitations of the ego } \\
\text { (McEwen and Schmidt, 2007) and } \\
\text { feedback is seen as essential (CC-23) for } \\
\text { learning and change but at the same } \\
\text { time it is taken lightly, sceptically } \\
\text { (Cook-Greuter, 2004) }\end{array}$ & $\begin{array}{l}\text { B7. Recognizes the existence of } \\
\text { a multitude of sustainability } \\
\text { definitions and is able to } \\
\text { connect them (Lynam, 2012)/is } \\
\text { able to integrate different } \\
\text { worldviews (BA-43) (McEwen } \\
\text { and Schmidt, 2007), brings } \\
\text { about societal transformations } \\
\text { (transforming self and others) } \\
\text { (Brown, 2011; Lynam, 2012), } \\
\text { reframes (Brown, 2011; Lynam, } \\
\text { 2012), holds up mirror to } \\
\text { society (BA-38) (Brown, 2011), } \\
\text { supportive of global } \\
\text { humanitarian causes (BA-41), } \\
\text { involved in multiple } \\
\text { organisations (BA-39) (Boiral } \\
\text { et al., 2009; Brown, 2011), often } \\
\text { works behind the scenes } \\
\text { (McEwen and Schmidt, 2007; } \\
\text { Brown, 2011) }\end{array}$ & $\begin{array}{l}\text { C7. Leading society-wide } \\
\text { transformations (Rooke and } \\
\text { Torbert, 2005; Brown, } \\
\text { 2011), active involvement } \\
\text { in transformation of the } \\
\text { organisation (BA-40) and } \\
\text { society, concern for } \\
\text { authenticity, truth and } \\
\text { transparency, has a } \\
\text { complex and integrated } \\
\text { vision (Boiral et al., 2009; } \\
\text { Brown, 2011) }\end{array}$ & $\begin{array}{l}\text { D7. Risk for diverging } \\
\text { managerial and } \\
\text { organisational efforts for } \\
\text { the benefit of the common } \\
\text { good, risk of losing touch } \\
\text { with the primary mission of } \\
\text { the organisation (Boiral } \\
\text { et al., 2009; Brown, 2011) }\end{array}$ \\
\hline
\end{tabular}

propose to create an analytical model that allows the analysis of the coherence between CS integration success, change agent worldviews and contextual factors. The type of factors influencing the integration process leads us to question what the interactions could be between the contextual factors, the change agent's worldview and the integration success. For example, a radical change with ample support of external stakeholders requires other interventions than an incremental change without the necessary resources (Lawrence and Lorsch, 1967 as used in Hatch and Cunliffe, 2013), but do these different situations also require change agents with different worldviews? A model could help to answer this question by identifying the type of change agent necessary for specific types of contexts, thereby contributing to the success of CS integration.

\subsection{The method}

To design the analytical model, the theory on worldviews and context factors was applied in a case study organisation. ${ }^{1}$ With the existing need for theory building on CS integration (Linnenluecke et al., 2009), case study research, as a valid method for theory building (Eisenhardt and Graebner, 2007; McCutcheon and Meredith, 1993), facilitates the exploration of CS change agents in organisational contexts. The outcomes of the case study served as practical knowledge to support the development of strategic goals of the case study organisation, as well as theoretical knowledge to add to the existing theory. Whereas the output of this research cannot be considered as generally applicable, its intention is to

\footnotetext{
1 A Dutch independent research institute funded by the government was used for the case study research. The research took place in a Dutch public organisation, RIVM, which counts 1500 employees and focuses on research in the field of public health and the environment, from where it draws up policy advice. RIVM is an independent research institute that is funded by the government and is working for among others the Dutch government and international clients such as the EU and UN.
} 
provide a both theoretical and practical perspective for the examination of CS integration cases as emphasized by Yin (1994).

The qualitative study consisted of three sub case studies: three projects assessed as relatively successful in terms of CS integration (as a result of the application of the LEAPFROCS method as described in Witjes, 2017; Witjes et al., 2017b) in a parallel research project in the same organisation (Denzel, 2016) and three involved change agents. By selecting multiple projects as separate case studies, the internal validity of the research was increased (Bryman, 2015).

\subsection{Data collection}

Data was collected on two topics: the context of the projects and the change agent worldviews. While the projects were already defined, the change agents were yet to be identified. The characterization of the projects' context supported in the identification of the change agent.

\subsubsection{Characterizing the context}

To start, in total 15 different organisational members connected to the projects were informally consulted in order to get a better view on the context of the projects. They were asked about the people involved, the steps that had already been taken, the planning of the projects and their role in the projects. Available documents concerning the projects were consulted to substantiate the view of the employees. These documents include a quick scan and policy document (project 1), pilot studies and evaluations (project 2 ), and a change map and acquisition PowerPoint presentation (project 3) (see Table 2). This resulted in an overall description of the context of the projects:

Project 1 represents the set-up of a CS policy document and describes the topics related to sustainability. The document also describes which sustainability ambitions the organisation has and how the institute aims to achieve them by 2020 . Though changing its structure over time, the project is led by a permanent team since the implementation of the policy remains a target in the future. In turn, project 2 aims at reducing paper use by working more digitally using a tablet or laptop instead of paper. This was attempted by executing different pilot projects in different departments. The execution of the project was temporary, for the duration of the overall programme, therefore the team can be described as a task force. Project 3 implies working to a method that focuses on achieving continuous, small enhancements in processes with a team. To that end, a core team collaborates on a weekly basis, now and in the future; it can therefore be considered a permanent team.

\subsubsection{Identifying the change agent}

With the identification of the change agent, an exploratory approach was taken. The description of each project, substantiated by the consultation of involved organisational members revealed several individuals with influential roles within the permanent teams and task force. The final selection was substantiated by linking back to the definitions of a change agent as stated in the theory. It was found that multiple possible change agents exist, but with regards to feasibility it was chosen to select one change agent per project. For the purpose of this research, the individuals with a perceived integrating role concerning the projects were selected. To facilitate the selection process, the people involved were also asked about their view on who they think is a change agent with regard to the projects. Together with the view of the researcher, this determined the final selection of the change agent. In practice, this meant that for project 1 , four possible change agents were identified. The person who promoted and managed the project at the time it was first set up was selected as change agent. Others were seen as change agents for 1 and 2) initiating the change process (person 1 and 2) and for currently taking over the project's coordination from our selected change agent (person 3). For project 2 , the person assigned as project leader was selected as change agent. Others were seen as change agents for initiating the project (person 1) and for managing the integration process (person 2 and 3). For project 3, four possible change agents were identified. The person currently in charge of the project's coordination was selected as change agent for this study. Others were seen as change agents for having an initiating, triggering role at the start of the project (person 1) and for being part of the core team around the project (person 2 and 3). Table 2 summarizes the first two steps in the data collection process, the characterization of the projects' contexts and the identification of the change agents.

\subsubsection{Change agent worldviews}

Data on change agent worldviews were collected by one in-

Table 2

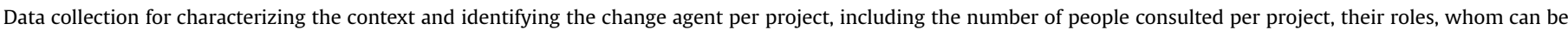
identified as change agents and the documents consulted for the description of each project. In italics are those individuals who were connected to multiple projects.

\begin{tabular}{|c|c|c|c|c|c|}
\hline Data collection & No. of people consulted & Roles within organisation & $\begin{array}{l}\text { No. of possible } \\
\text { change agents }\end{array}$ & $\begin{array}{l}\text { No. of documents } \\
\text { consulted }\end{array}$ & Document type/source \\
\hline Project 1 & 5 & $\begin{array}{l}\text { - Department Head Sustainability, } \\
\text { Drinking Water \& Soil } \\
\text { - Head of Purchasing Performance Center, } \\
\text { customer and supplier management } \\
\text { - Deputy Director General } \\
\text { - Staff Chief General \& Technical Service } \\
\text { - Deputy Head Human Resource Management }\end{array}$ & 4 & 2 & - Report \\
\hline Project 2 & 7 & $\begin{array}{l}\text { - Information Manager } \\
\text { - Director General } \\
\text { - Project leader/Lean professional } \\
\text { - Project leader (2) } \\
\text { - Deputy Head Human Resource Management } \\
\text { - Program Leader }\end{array}$ & 3 & 5 & $\begin{array}{l}\text { - PowerPoint } \\
\text { - Intranet } \\
\text { - Report }\end{array}$ \\
\hline Project 3 & 5 & $\begin{array}{l}\text { - Deputy Director General } \\
\text { - Project leader, manager } \\
\text { - Coordinator } \\
\text { - Head Secretariat \& Management } \\
\text { - Consultant/Program manager }\end{array}$ & 4 & 2 & $\begin{array}{l}\text { - Infographic } \\
\text { - PowerPoint }\end{array}$ \\
\hline
\end{tabular}




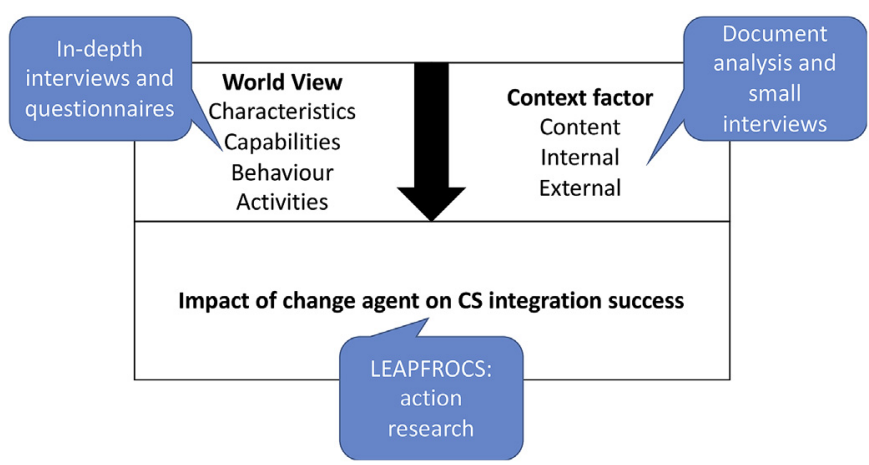

Fig. 1. Analytical model in which worldviews and the context factors of the integration process are assumed to influence the impact of a change agent on the success of CS integration and are to be assessed using a multimethod approach.

depth interview and two questionnaires per case study (per change agent). ${ }^{2}$ The purpose of both the interview and the questionnaires was to find out which worldview the change agent holds, or of which range of worldviews the change agent shows most elements. In this case, elements refer to both characteristics and capabilities or behaviour and activities of the change agent as presented in Table 1 (see section 2.2.1). The 23 highlighted characterises capabilities (identified and shown as codes CC- 1 until CC-23) are used for this analysis, as well as the highlighted behaviours and activities (identified and shows as codes BA-24 until BA-43).

Fig. 1 visualizes the proposed analytical model, linking change agents and CS integration, in which worldviews and the context factors of the integration process are assumed to influence the impact of a change agent on the success of CS integration. The model consists of a multimethod approach in which we use qualitative methods such as interviews and document consultation, in combination with quantitative survey elements and the practical orientation represented by action research (Denzel, 2016).

\subsection{Data analysis}

The results of both questionnaires and the separate interviews were analysed by grouping together the elements covering each specific worldview, and those covering a range of worldviews. The interview transcripts were analysed by selecting quotes and analysing them based on what was said directly in the quote, combined with an analysis of what the change agent said earlier or later in the interview. It should be noted that describing worldviews is done on the basis of one's own worldview or by the specific way in which one approaches and identifies an individual as a research subject (Van Opstal and Hugé, 2013). Therefore, ethnocentrism and researcher bias may have occurred.

In the overall analysis, an investigation was made of the extent to which the success of the CS integration was determined by the change agent (worldview) and to which extent it was determined by contextual factors. This was done according to Eisenhardt's method of within- and cross-case analysis (Eisenhardt, 1989): the data for each sub case was compared so that similarities and differences could be discerned. The data analysis has improved the preliminary framework by giving an indication of the influence of a change agent in the process of CS integration. A detailed description of among others the projects, respondent selection, research

\footnotetext{
${ }^{2}$ Data on worldviews are normally obtained by psychological analyses (e.g. Sentence completion Tests (Loevinger, 1985),) but for reasons of time and means availability, for this particular research it was decided to develop a different method.
}

instruments and methods of analysis is available (see Van den Berg, 2016) to increase the replicability of the study (Bryman, 2015).

\section{Case study results}

To illustrate the analytical model, this section shows an overview of the different results obtained, existing of the different contextual factors found to be of influence on the change processes represented by project 1,2 and 3 (section 4.1.), and the worldviews of the change agents found to be in characteristics and capabilities or behaviour and activities (section 4.2.).

\subsection{Contextual factors}

\subsubsection{Content factors}

Type of change The motivation and activity for project 1 originated mainly from the operational part of the organisation and links to related, already ongoing projects. As a result of this, it is seen as initiating a redirection of changes that are already taking place, indicating an incremental, continuous change. Project 2 is seen as the result of a misalignment between the organisation's structure (based on working with paper) and environmental demands (working digitally) and therefore represents a radical change. Strong strategic motivation further implies a top-down approach. Project 3 mainly impacts the way people work and the way processes take place, a characteristic typical to incremental change. The focus is integrating the project within the organisation via a bottom-up approach.

\subsubsection{Internal factors}

Strategy Project 1 is not officially included in the organisation's strategy. However, a clear link exists between the project's topic and some of the key success factors from the organisation's strategy. Since project 2 was part of an already existing program connected to the organisation's strategy, its integration is an official target for the organisation. Like project 2, project 3 is officially part of organisation's strategy and thus is an official Key Performance Indicator (KPI) for the organisation.

Planning For project 1, the document concludes with a plan including different targets for each theme (e.g. waste management). However, the plan did not include a clear strategy: there were no clear targets or objectives formulated. For project 2 and 3 a plan and a course of action (project 2) and a plan combined with objectives (change map, project 3) were developed.

Collaboration or involvement of employees For project 1 , there was no official team around the policy, but there were a number of sub-teams that all contributed, including teams from operations and primary process. For project 2, three pilots in different departments were undertaken. During the pilots, there was collaboration between organisational members working on the pilots. For project 2, the participating employees of the different pilot departments were not actively involved in the process. Nonetheless, a positive attitude of most participating employees with respect to the project existed. For project 3, a core team collaborated on a weekly basis. When it came to involving others, it is not clear how this was dealt with in project 1 and 3, possibly indicating that employees could have been more actively included in the projects.

Communication For project 1, official communication other than the policy document itself was absent. This communication also lacked a clear vision, a sense of urgency, an explanation of why the change should be pursued and why this particular strategy was the right way to do it. With respect to project 2, there was clear communication of a vision and the purpose of the pilots and their process. Communication went via the pilot groups as well as via 
Table 3

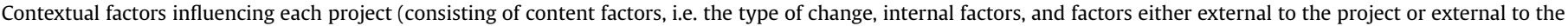
organisation).

\begin{tabular}{|c|c|c|c|c|}
\hline \multirow[t]{2}{*}{ Content factor } & \multirow[t]{2}{*}{ Type of change } & \multirow{2}{*}{ 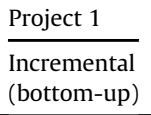 } & \multirow{2}{*}{$\begin{array}{l}\text { Project } 2 \\
\text { Radical } \\
\text { (top-down) }\end{array}$} & \multirow{2}{*}{$\begin{array}{l}\text { Project } 3 \\
\text { Incremental } \\
\text { (bottom-up) }\end{array}$} \\
\hline & & & & \\
\hline \multirow[t]{10}{*}{ Internal } & Collaboration & V & $\mathrm{V}$ & $\mathrm{V}$ \\
\hline & Communication & & $\mathrm{V}$ & $\mathrm{V}$ \\
\hline & Evaluation \& Monitoring & & $\mathrm{V}$ & V \\
\hline & Measuring \& Adjustment & & $\mathrm{V}$ & V \\
\hline & Strategy & & $\mathrm{V}$ & V \\
\hline & Planning & V & $\mathrm{V}$ & $\mathrm{V}$ \\
\hline & Setting relevant and realistic objectives & & & \\
\hline & Involvement of organisational members & & $\mathrm{X}$ & \\
\hline & Reorganisation of roles and responsibilities & & & $\mathrm{V}$ \\
\hline & Postponing implementation & $\mathrm{V}$ & & \\
\hline \multirow[t]{5}{*}{ External (to project) } & Management support \& commitment & $\mathrm{X}$ & $\mathrm{V}$ & $\mathrm{X}$ \\
\hline & Underutilization of resources & V & & \\
\hline & Lack of knowledge & & $\mathrm{V}$ & \\
\hline & Specialized knowledge & & $\mathrm{V}$ & $\mathrm{V}$ \\
\hline & Consistency with image/identity & V & $\mathrm{V}$ & V \\
\hline \multirow[t]{2}{*}{ External (to organisation) } & Technological changes & & $\mathrm{V}$ & \\
\hline & Government as a role model & V & V & \\
\hline
\end{tabular}

intranet, presentations and evaluation documents. For project 3, the planning and combined objectives are communicated via e.g. intranet, in wiki ${ }^{3}$ and flyers in the cafeteria, specifically on the why and how of the project. This communication seemed to lack a sense of urgency and explicit communication of the benefits of the project.

Evaluation and measuring There was no official monitoring and evaluation of project 1 . For project 2 , all pilots have been evaluated, and employees who participated in the pilots experienced project 2 as efficient and effective. These evaluations coupled with subsequent recommended adjustments show that monitoring, evaluating and adjusting were part of the integration process. For project 3 , the effects of each subproject were measured. It seems that monitoring and evaluation and maintenance, support and improvement took place.

Reorganisation of roles and responsibilities/0ther factors related to the projects Particularly worth noting for project 3 , is that the subprojects usually resulted in a reorganisation of roles and responsibilities of organisational members. For project 1 , it is worth noting that its implementation had been postponed whilst considering other strategies.

\subsubsection{External factors}

3.1.3.1. Factors external to the project. Management support and commitment There was a lack of management support for project 1. In contrast, project 2 was initiated and motivated by the DirectorGeneral. The initiative of the highest member of the board eventually offset the lack of enthusiasm among other members of the board. The integration of project 3, although initiated by someone in a strategic position, also seemed hampered by a lack of full management support and commitment since other strategic position staff were not fully supportive of the project.

Underutilization of resources For project 1, an inventory was made on which models were available and whether they were used. It turned out that most available models were not yet being used their full extend, indicating an underutilization of resources. For project 2 and 3, there was no information on the availability and deployment of resources.

Lack of knowledge For project 2, team members had expertise

\footnotetext{
${ }^{3}$ Communication applications for case study organisation.
}

but lacked sufficient knowledge with respect to the safe use of the devices. This was acknowledged but the implementation of the project was pursued anyway for reasons of strong strategic motivation.

Specialized knowledge Training of employees to become specialists in project 3 have resulted in the presence of specialized knowledge and expertise.

Consistency with image or identity All projects seem to be consistent with the identity and image of the organisation, which is based on time and place independent working and commitment to sustainability.

3.1.3.2. Factors external to the organisation. Government as a role model In the documentation of project 1 it is noted that the corporate world wants the government to create a more challenging environment when it comes to sustainability and it is mentioned that the organisation, being a public research institute, should respond to this request. For the initiation of project 2, the fact that the Dutch Parliament has also started to work digitally was mentioned as a driver to pursue the same within the case study organisation.

Technological changes For project 2, there were possibilities to do it differently through the application of iPads. For project 1 and 3 , no such technological possibilities were relevant.

Contextual factors influencing each project are presented in Table 3. A ' $\mathrm{V}$ ' indicates that the specific factor was found present with regard to the project, while an $\mathrm{X}$ indicates that it was found that the factor was not present. When neither $\mathrm{X}$ or $\mathrm{V}$ is shown, this indicates that no data on this factor were found with respect to the project.

\subsection{Change agent worldviews}

A brief overview is given below of the results concerning the change agent worldviews by using interview quotes and by referring to questionnaire answers. To make it concise, we elaborate on only the most significant results.

\subsubsection{Characteristics and capabilities}

In Table 4, an overview is given of the characteristics and capabilities (abbreviated as CC) that were investigated for all change agents, ranging from $\mathrm{CC}-1$ (impulsive) to $\mathrm{CC}-23$ (likes to receive 
Table 4

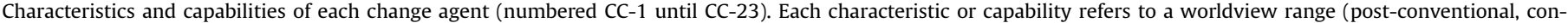
ventional or pre-conventional) or a specific worldview.

\begin{tabular}{|c|c|c|c|c|c|c|c|}
\hline \multirow{2}{*}{$\begin{array}{l}\text { Worldview (Code as given } \\
\text { in first column, Table } 1 \text { ) }\end{array}$} & \multirow[t]{2}{*}{ (range) } & & \multicolumn{2}{|c|}{ Characteristics/capabilities } & \multirow[t]{2}{*}{ CA1 } & \multirow[t]{2}{*}{ CA2 } & \multirow[t]{2}{*}{ CA3 } \\
\hline & & & $\begin{array}{l}\text { Nr. (Code Table } 1, \\
\text { Column A) }\end{array}$ & & & & \\
\hline \multirow[t]{2}{*}{ Opportunist (A1) } & Pre-conv. & & $\mathrm{CC}-1$ & Impulsive & & & \\
\hline & & & CC-2 & Demanding & & & \\
\hline \multirow{2}{*}{ Diplomat (A2) } & Conventional & All (Pre-) Conventional & $\mathrm{CC}-3$ & Wants to belong & & & \\
\hline & & & CC- 4 & Conventional & & & \\
\hline \multirow[t]{2}{*}{ Expert (A3) } & & & CC-5 & Perfectionist & & $\mathrm{V}$ & \\
\hline & & & CC-6 & Wants to be unique & & & \\
\hline \multirow[t]{2}{*}{ Achiever (A4) } & & & $\mathrm{CC}-7$ & Responsible & $\mathrm{V}$ & $\mathrm{V}$ & \\
\hline & & & CC-8 & Reflective & $\mathrm{V}$ & $\mathrm{V}$ & \\
\hline$(\mathrm{A} 1-\mathrm{A} 4)$ & & & CC-9 & Wants to be in control & & VV & $\mathrm{V}$ \\
\hline \multirow[t]{2}{*}{ Individualist A5 } & Post-conventional & All Post-conventional & CC-10 & $\begin{array}{l}\text { Values relationships over } \\
\text { achievements }\end{array}$ & $\mathrm{V}$ & & \\
\hline & & & CC-11 & Tolerant & VV & VV & $\mathrm{V}$ \\
\hline Strategist A6 & & & CC-12 & Likes to collaborate & $\overline{\mathrm{VV}}$ & $\overline{\mathrm{VV}}$ & $\underline{\mathrm{VV}}$ \\
\hline \multirow[t]{2}{*}{ Alchemist A7 } & & & CC-13 & Charismatic & & $\overline{\mathrm{V}}$ & $\overline{\mathrm{V}}$ \\
\hline & & & CC-14 & Wise & & & \\
\hline \multirow[t]{9}{*}{ (A5-A6-A7) } & & & CC-15 & Self-aware & $\underline{\mathrm{VV}}$ & $\underline{\mathrm{VV}}$ & $\underline{\mathrm{VV}}$ \\
\hline & & & CC-16 & Enhanced systems consciousness & $\overline{\mathrm{VV}}$ & & $\overline{\mathrm{V}}$ \\
\hline & & & CC-17 & Handles uncertainties well & $\overline{\mathrm{VV}}$ & & $\underline{\mathrm{VV}}$ \\
\hline & & & CC-18 & Awareness of conflicting viewpoints & $\overline{\mathrm{V}}$ & & $\overline{\mathrm{VV}}$ \\
\hline & & & CC-19 & $\begin{array}{l}\text { Capacity to understand people } \\
\text { with conflicting viewpoints }\end{array}$ & $\mathrm{V}$ & $\mathrm{V}$ & \\
\hline & & & CC-20 & $\begin{array}{l}\text { Interacts well with people holding } \\
\text { different viewpoints }\end{array}$ & $\mathrm{V}$ & $\underline{\mathrm{VV}}$ & $\underline{\mathrm{VV}}$ \\
\hline & & & CC-21 & Handles conflicts well & $\mathrm{V}$ & $\mathrm{V}$ & \\
\hline & & & CC-22 & $\begin{array}{l}\text { Awareness of conflicting inner emotions } \\
\text { and capacity to integrate them }\end{array}$ & $\mathrm{V}$ & & \\
\hline & & & CC-23 & Likes to receive feedback & & & $\mathrm{V}$ \\
\hline
\end{tabular}

feedback), as explained in section 3.1.3. All change agents ${ }^{4}$ are considered as tolerant (CC-11) by their colleagues and by themselves, especially CA1 and CA2, indicating an Individualist worldview. All three change agents appear to be self-aware (CC -15) to the same extent (according to the questionnaire answers), indicating a more post-conventional worldview. For example, CA3 said: “(..) ... I was always very much thinking like 'oh we have a problem, oh, let's solve it', you know, dive fast into the solution and what you learn from *project $3^{*}$ is, crazy enough maybe, to sit back and consult with each other like 'what is the problem really? Where is it? Who is bothered by it? What are the causes?' "[Quote 1] As this quote indicates a change in her way of thinking, and especially her own realization of this change, it was interpreted as showing a high level of selfawareness.

All change agents to the same extent like to collaborate (CC-12), indicating a Strategist worldview. CA1 noticed about her work in project 1 the following: "Especially working with other people who were also enthusiastic about sustainability ... (..). But especially working together with others, then you feel that something is flowing so to say."[Quote 2] As CA1 explicitly mentions she likes to work together with other people, this was interpreted as an indication of her preference for collaboration.

All change agents (especially CA2 and CA3) seem to be able to interact with people holding different viewpoints (CC-20), indicating a post-conventional worldview. CA2 notes the following about people resisting participation in project 2: "And there have been a few people that remained with that [resistance] and then we said 'ok, then you have the option, then you just don't participate in this pilot right now, return the tablet. Just return to the old way of

\footnotetext{
${ }^{4}$ Each change agent (CA) is referred to as change agent 1,2 or 3, or CA1, CA2 and CA3 respectively. In accordance, CA1 is connected to project 1, CA2 to project 2 , and CA3 to project 3 .
}

working, fine, also ok." [Quote 3]. This quote was interpreted as an indication of his capability to interact with people holding different viewpoints. CA2 met quite some resistance of others to participate in the project, he appeared to be able to handle this resistance with clear wording and an open attitude, without arguing with those involved.

CA3, but particularly CA1, show a more enhanced systems consciousness (CC-16) in contrast to CA2, indicating a postconventional worldview. For example, CA1 reflects on sustainability on a personal level, work level or even a global level: "You can make it really big, but you can also keep it small [sustainability]. I think in any case that if you make it really big, we first have to make sure we continue to be able to populate the world well, that we can live on it well. That I can leave the planet to my children, if I am not there anymore at one point. Small, then I think here, at [case study organisation 1 (.... ) and for me it is even smaller, it is actually a kind of way of life." [Quote 4] As systems consciousness, or systems thinking implies that one is aware of the interconnectedness between and interdependence of systems, CA1 realizes that the system she is part of (personal level, work level) are not just systems in themselves but are connected and part of an even bigger system (global level).

CA1 thinks relationships are more important than achievements (CC-10), indicating an Individualist worldview. As sole change agent, she showed clear awareness of her conflicting emotions (CC22 ), indicating a post-conventional worldview. For example, when she reflects upon a sustainable initiative that never took off because there were bureaucratic and safety issues involved: “(..). it is a little bit of a head-heart discussion that you have then actually." [Quote 5] Though she knows rationally that it is better not to continue the initiative, she still feels as though she still wants to continue. Because she explicitly states that her head and 'heart' are not on the same page, this quote was interpreted as indication of an awareness of inner conflicts. 
Table 5

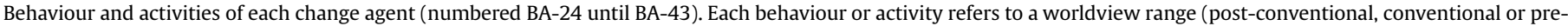
conventional) or a specific worldview.

\begin{tabular}{|c|c|c|c|c|c|c|}
\hline \multirow{2}{*}{$\begin{array}{l}\text { Worldview (Code as given } \\
\text { in first column, Table } 1 \text { ) }\end{array}$} & \multirow[t]{2}{*}{ (range) } & \multicolumn{2}{|l|}{ Behaviours/activities } & \multirow[t]{2}{*}{ CA1 } & \multirow[t]{2}{*}{ CA2 } & \multirow[t]{2}{*}{ CA3 } \\
\hline & & $\begin{array}{l}\text { Nr. (Code Table } 1, \\
\text { Column B, C and D) }\end{array}$ & & & & \\
\hline Opportunist & Pre-conv. & $\begin{array}{l}\text { BA-24 } \\
\text { BA-25 }\end{array}$ & $\begin{array}{l}\text { Takes measures that are focused on the short term } \\
\text { Is only involved because it affects him/her personally }\end{array}$ & $\mathrm{V}$ & & \\
\hline Diplomat & Conventional & $\begin{array}{l}\text { BA-26 } \\
\text { BA-27 } \\
\text { BA-28 }\end{array}$ & $\begin{array}{l}\text { Focused on expectations and approval of others } \\
\text { Focused on the image of the organisation with respect to sustainability } \\
\text { Often makes statements that are not in line with his/her behaviour }\end{array}$ & $\mathrm{V}$ & $\begin{array}{l}\mathrm{V} \\
\mathrm{V}\end{array}$ & $\mathrm{V}$ \\
\hline Expert & & BA-29 & Approached the project from a specialized perspective & & & $\mathrm{V}$ \\
\hline & & BA-30 & Focused on knowledge development & $\mathrm{V}$ & $\mathrm{V}$ & $\mathrm{V}$ \\
\hline Achiever & & $\begin{array}{l}\text { BA-31 } \\
\text { BA-32 }\end{array}$ & $\begin{array}{l}\text { Focused on improving performance } \\
\text { Focused on actions and targets }\end{array}$ & & $\begin{array}{l}\mathrm{V} \\
\mathrm{VV}\end{array}$ & $\begin{array}{l}\mathrm{V} \\
\mathrm{V}\end{array}$ \\
\hline Individualist & Post-conventional & $\begin{array}{l}\text { BA-33 } \\
\text { BA-34 } \\
\text { BA-35 }\end{array}$ & $\begin{array}{l}\text { Develops creative and original solutions } \\
\text { Personally committed } \\
\text { Creates new rules if existing ones are considered irrelevant }\end{array}$ & $\begin{array}{l}\mathrm{V} \\
\underline{\mathrm{VV}}\end{array}$ & $\begin{array}{l}\mathrm{V} \\
\mathrm{V}\end{array}$ & $\begin{array}{l}\mathrm{V} \\
\mathrm{V} \\
\mathrm{V}\end{array}$ \\
\hline Strategist & & $\begin{array}{l}\text { BA-36 } \\
\text { BA-37 }\end{array}$ & $\begin{array}{l}\text { Handles resistance of colleagues well } \\
\text { Capable of creating shared visions among people with different viewpoints }\end{array}$ & $\mathrm{V}$ & $\underline{\mathrm{VV}}$ & $\frac{\mathrm{VV}}{\mathrm{V}}$ \\
\hline Alchemist & & $\begin{array}{l}\text { BA-38 } \\
\text { BA-39 }\end{array}$ & $\begin{array}{l}\text { Holds up a mirror/confronts you with your own way of thinking } \\
\text { Involved in multiple organisations }\end{array}$ & $\mathrm{V}$ & V & $\mathrm{V}$ \\
\hline & & $\mathrm{BA}-40$ & Pursues transformation of the organisation & $\mathrm{V}$ & $\mathrm{V}$ & $\mathrm{V}$ \\
\hline (A5-A6-A7) & & $\begin{array}{l}\text { BA-41 } \\
\text { BA-42 } \\
\text { BA-43 }\end{array}$ & $\begin{array}{l}\text { Thinks in the longer term } \\
\text { Has an integrative focus on sustainability }\end{array}$ & $\begin{array}{l}\mathrm{V} \\
\mathrm{V}\end{array}$ & $\mathrm{V}$ & \\
\hline
\end{tabular}

In contrast to CA2, CA1 and CA3 clearly show that they can handle uncertainties well (CC-17), indicating a post-conventional worldview. CA3 states for example: "Look, how bad it was exactly in the past, we will never know, those data are not there, but we all experience it like 'ok, there is a problem and we are bothered by it. We cannot measure it but there is a problem ... we accept that."' [Quote 6] She shows herself as accepting that she cannot control things she doesn't know, which was seen as an indication of her capability to handle uncertainties.

CA3 most clearly likes to receive feedback (CC-23), indicating a post-conventional worldview as became clear from the questionnaires as well as the interview: “(..).it was also partly behaviour that I partly caused myself and then it is good that someone holds a mirror up to you ... (..) [Quote 7] This quote reflects that CA3 appreciates someone confronting her with her own behaviour and why that may lead to something undesirable. For this reason, it was interpreted as an indication of a positive attitude towards receiving feedback.

When considering the seven worldviews, CA1 was found to show most distinct characteristics and capabilities reflecting an Achiever or Individualist worldview (e.g. CC-7,8,10,11). In contrast to the other change agents, she shows more elements indicating a post-conventional worldview range. In turn, CA2 shows an even distribution of characteristics and capabilities among the Expert to Alchemist worldview. While CA2 shows a specific characteristic of the Expert worldview (Perfectionist, CC-5), CA1 and CA3 do not show any characteristics of the (pre-)conventional worldview range (Opportunist - Expert) in the questionnaire results. More clearly than CA3, CA2 wants to be in control (CC-14), indicating a more conventional worldview range. Fewer elements were found indicating a post-conventional worldview range for CA2 in comparison to CA1 and CA3. Finally, CA3 shows a distribution of characteristics and capabilities among the Individualist to Alchemist worldview, but also likes to be in control, which is interpreted as more indicative of a (pre)conventional worldview range. It is worth noting that she does not show specific characteristics of the Opportunist, Diplomat or Expert worldviews (CC-1-6) according to the questionnaire results. As CA1, she shows relatively many elements indicating a post-conventional worldview range.
Table 4 shows the characteristics and capabilities that were investigated among the change agents. As deduced from the interviews and questionnaires, each change agent shows certain characteristics (numbered CC- 1 until CC-23). Elements either apply to the change agent or strongly apply to the change agent (in bold and underlined: $\mathbf{V V}$ ), ${ }^{5}$ to a normal extent (as V) or not (blank space). ${ }^{6}$ Each characteristic or capability refers to a worldview range (post-conventional, conventional or pre-conventional) or a specific worldview, which can be traced back via the corresponding code in Table 1 consisting of the letters CC and a number.

\subsubsection{Behaviour and activities}

In a comparable way we assessed the behaviours and activities, as outlined in Table 5 . Here, we used codes abbreviating behaviours and activities (BA), ranging from BA-24 (takes measures that are focused on the short term) to BA-43 (capable of reframing/challenging existing ideas and assumptions). All change agents appear to be personally committed (BA-34) (Individualist) to their work related to their projects, but CA1 shows the strongest signs of personal commitment during the interview. For example, she feels emotionally involved in the climate case: "That Marjan Minnesma arrives at the symposium and you keep following her a little. That has a special meaning ... and that climate case also really moved me so to say." [Quote 8] Since this statement shows a more emotional feeling towards sustainability, it was seen as a sign that sustainability not only motivates her on a professional level, but also on a personal level, which was then translated as her being personally committed.

All change agents were found to be focused on the expectations and approval of others (BA-26) (Diplomat), on knowledge

\footnotetext{
5 The distinction between applied and strongly applied rests on the fact that elements that strongly applied were found applicable to the same extent by both the change agent and/or all three colleagues (questionnaires) and/or were strongly reflected by the interviews (either by the clarity of the quote itself or the total number of quotes all indicating the same).

6 The last option could both indicate that this element was found NOT to be applicable to the change agent or simply did not come forward in either the interview or questionnaires.
} 
development (BA-30) (Expert), and were considered to be able to handle the resistance of colleagues well (BA-36) (Strategist). For example, as CA3 noticed about uncooperative colleagues: "People often have to, so to say, get out of the resistance, or first get out of the fear before they can start to build. It is a change curve, with changes, people actually go a little bit through a change curve. At first there is denial, subsequently they get angry, then they become frustrated or ... and then they can start to climb again. You first have to pull them through the curve before you can move on with them." [Quote 12] As she shows herself to be aware of what drives people's resistance and how they can overcome it, this was interpreted as a sign of her capability to handle colleagues' resistance. Finally, all change agents are considered to pursue transformation of the organisation (BA-40) (Alchemist).

With respect to sustainability itself, CA1 shows with Quote 4 that she can place sustainability in a wider context and was thus seen as having an integrative focus on sustainability (BA-42), indicative of a post-conventional worldview. CA1 was considered by her colleagues as being focused on the short term (BA-24) (Opportunist) while in the interview she simultaneously appeared to be involved in multiple organisations with respect to sustainability (BA-39) (Alchemist). CA2 seems especially focused on actions and targets (BA-32), indicating an Achiever worldview. For example, he notes the following: "Well for projects, at least there should be a goal, where do we work towards, that is something I myself think is important." [Quote 9] CA2 expressed in this and other quotes that he prefers to have a clear goal for a project, which was subsequently translated into a focus on actions and targets. CA2 seems mostly focused on the image of the organisation (BA-27) (Diplomat) with respect to sustainability: "Even if it is just only for the image ... all these piles of paper, no that is not appropriate for these times anymore." [Quote 10] CA2 shows clear capability to challenge and reframe existing ideas and assumptions (BA-43), indicating a post-conventional worldview. For example, he recognizes the need for the organisation to spend time during meetings differently: (..) ... pretty quickly the awareness arose like 'we can use our time in meetings also more effectively' and then I also thought 'yes', I agreed with that completely, I still do. We can win so much time, there are so many meetings being held in such an inefficient way (..)" [Quote 11] This statement shows that the current ideas and assumptions about how to fill meetings do not consider how they can become more efficient and less time consuming. CA2 is not afraid to challenge this line of thinking and expresses that he would like to change the way things are being done. CA3 was considered to approach the project from a specialized perspective (BA-29) (Expert) and capable of creating shared visions among people with different viewpoints (BA-37) (Strategist).

All change agents thus show a broader range of behaviour and activities among the worldviews, even including the Opportunist (CA1) and Diplomat (CA1,2,3) worldview. As CA1 shows most clear signs of an Individualist worldview, CA2 seems to represent the Achiever worldview in his behaviour. CA3 equally appears to be an Individualist as well as a Strategist. While CA2 showed the least elements of a post-conventional worldview range in his characteristics, it is the other way around for his behaviour. Table 5 shows which behaviours and activities were found applicable to each change agent (indicated by the last 3 columns in Table 5) and to what extent (numbered BA24 until BA-43). Each behaviour or activity (first column in Table 5) refers to a worldview range (postconventional, conventional or pre-conventional; second column in Table 5) or a specific worldview, which can be traced back via the corresponding code in Table 1, consisting of the letters BA and a number as also used in the first column of Table 5. Elements either apply to the change agent (indicated by a V) or strongly apply to the change agent (in bold $\mathbf{V V}$ ).

\section{Case study analysis}

All change agents were involved in relatively successful projects concerning the integration of CS, of which most discernible were the in general negative context of the change process for project 1 and the relatively positive context for project 2 and 3 . Though some variation exists for each change agent in both the broader worldview elements (characteristics, capabilities and behaviours, activities combined) as well as the specific elements, all change agents seem fairly consistent in their worldview. That is, simultaneously considering both characteristics and behaviour, CA1 reflects the Individualist worldview, CA2 the Achiever worldview and CA3 the Strategist worldview.

When taking the contextual factors and worldviews together, a few things are worth mentioning. First, change processes characterized by incremental change (projects 1 and 3) and a lack of management support and commitment involve change agents with Individualist (CA1) and Strategist (CA3) characteristics. Second, a radical change process, with strong management support involves a change agent with, in general, more conventional behaviour (Achiever, CA2). As all three projects were relatively evenly successful, it could be interpreted that a change process lacking full management support (and is thus pursued more bottom-up) requires a bigger influence by the change agent him or herself and therefore requires a change agent with more post-conventional characteristics. Conversely, a change process that already is supported by the strategic level of the organisation might require less influence by the change agent, and therefore someone with less post-conventional behaviour, such as that of the Achiever. As collaboration seem to be part of each project, this also coincides with the collaborative nature of all three change agents. As project 2 and 3 both experienced the positive influence of the presence of communication, evaluation and monitoring, measuring and adjustment, a strategy and planning, and project 1 did not, it could be argued that the role of CA1 was more vital in the change success of project 1 . Thus, it could be that the worldview level of a change agent becomes more important in the case of a change project with a context that mostly hampers CS integration (mostly a lack of management commitment), and vice versa.

Some contextual factors appear to interact directly with the change agent's worldview, others more indirectly. For example, internal (process related) factors are within the change agent's ability to influence: communication or evaluation of the change process are activities which the change agent can undertake his or herself or appoint another organisational member to do so. On the other hand, whether the change process is of an incremental or radical nature (content factor) is beyond the change agent's control. The change agent could, however, improve the change process by approaching the nature of the change process in a fashion that is required by the type of change. Therefore, it can be argued that there is an indirect interaction between the change agent worldview and the context of the change process.

When combining the most notable scores of each CA per worldview (Tables 4 and 5) and the contextual factors (Table 3) which showed a clear score for each project, the following results can be distinguished in Table 6.

Not surprisingly, all change processes include a planning (internal factor) and are consistent with the image of the organisation (external factor). It goes without saying that a change process that is not planned or does not align with what the organisation stands for, will not succeed to begin with. So, what mostly stands out from Table 6 is, the type of change (content factor), the presence or absence of management support and commitment (external factor) and how these two factors relate to worldview type of the change agent. 
Table 6

Key results of worldview combinations and contextual factors determining the change process.

\begin{tabular}{|c|c|c|c|c|}
\hline Worldview & & Achiever & Individualist & Strategist \\
\hline Type of change & & Radical & Incremental & Incremental \\
\hline \multirow[t]{3}{*}{ Determining factor } & Planning & Yes & Yes & Yes \\
\hline & Management support and commitment & Yes & No & No \\
\hline & Consistency with image organisation & Yes & Yes & Yes \\
\hline
\end{tabular}

For example, with regards to CA2 (Achiever), the fact that he had a clear focus on targets as well as the capability to challenge and reframe existing ideas and assumptions (see Table 5) likely matched well with the radical nature of the change process. That is, other organisational members' hesitation and resistance towards the change arguably necessitated a change agent who made them challenge their own mindsets as well as stays on top of targets. In line with this, when management support is present, it is easier for the change agent to stay on top of those goals. By contrast, more incremental change processes without clear management support apparently needed change agents with more postconventional worldviews. To be precise, these change agents (CA1 and CA3) showed the capability of handling uncertainties well and were able to develop creative and original solutions, in contrast to CA2. The absence of management support, or in this case probably the absence of an upfront beaten pathway to be followed by the change agents, required them to come up with solutions themselves. Inherent to such a lack of guidance, these change agents found relatively many uncertainties on their journey and thus necessitating them to be able to handle these.

All data together thus reflect a heterogeneous image of the organisation with respect to CS integration. Indeed, as CS integration is considered a certain type of process, the results show that it is more likely to be a process that can be defined in different ways, depending on certain organisation- and project-bound characteristics. Results indicate that CS integration is not always characterized by one type of context and therefore does not always require the same type of worldview in a change agent.

\section{Discussion}

The aim of this paper was to contribute to the understanding of change agents and their contribution to CS integration by proposing and illustrating an analytical model. The model has been based on literature concerning worldviews and context factors of change agents contributing in a positive way to the integration of CS into the organisational setting. A single case study has been used to illustrate the model.

\subsection{Lessons from the case study}

The case study shows that the analytical model is operational and results in information on CA worldviews and contextual factors that is that can be combined in such a way that it creates insights into the influence of change agents on the success of CS integration. Also, the case study shows that interpretation of the results in terms of change agents' influence and the role of their worldviews is challenging and three projects do not provide enough material to detect patterns on the interplay between worldviews, contextual factors and CS integration success. With the wide diversity of worldviews and context conditions, a wider set of cases is needed to arrive at general patterns. But with the proposed model we developed a new way of analyzing which was not yet available in literature. On the other hand, some of the results align with what can be found in literature. For example, Petersen et al. (2004) discuss that incremental change is usually bottom-up implemented while radical change is top-down implemented. While the first holds for project 1 and 3, project 2 showed clear signs of the latter type of change. As project 1 and 3 seemed to be projects with a longer time span, initially set up with an indefinite ending time, they were intended to alter the organisation step by step, as already mentioned by Walker et al. (2007) as a characteristic of incremental change. Conversely, project 2 was meant to cover a certain, limited period in which it was intended to become successful, clearly planned by top management, which was also marked as a feature of radical change (Petersen et al., 2004). The lack of (full) management support and commitment for project 1 and 3 and its clear presence in project 2 were found to be of important influence on the projects' success, as supported by existing literature (e.g. Fernandez and Rainey, 2006; Herron and Hicks, 2008; Walker et al., 2007; Stelzer and Mellis, 1998).

On the other hand, where literature seems to agree that a change process is most benefited by a change agent with a postconventional worldview (e.g. Brown, 2012; Rooke and Torbert, 2005), this case study shows that this is not necessarily true, given the fact that all three projects were equally successful. The results provide more support for the hypothesis that contextspecific factors determine which worldview is most beneficial (e.g. Boiral et al., 2009). That is, someone with a more conventional worldview might better adapt to the specific context of the organisation than a change agent with a post-conventional worldview (Boiral et al., 2009).

Furthermore, the case study revealed that the change agents do not hold one worldview, but rather a worldview profile. That is, a unique combination of characteristics and behaviours of different worldviews as described in literature. Indeed, change agents act according to a spectrum of worldviews showing elements of several worldviews at the same time, though each to a greater or lesser extent (O'loughlin, 2011). Although the change agents have different worldviews and the projects showed different contextual characteristics, all projects were considered equally successful. This result underlines that the success of a change agent is determined by both contextual factors and the change agent's worldview.

\subsection{Implications for theory and practice}

We developed an analytical model that supports exploration of the influence of the worldviews of change agents on the success of integration of corporate sustainability in an organisation. The model is derived from interview, survey and review techniques.

With the review, the resulting analytical model and the illustrative case study we contribute to theory building and operationalization of previously ill-defined terms such as worldviews and CS integration processes. We build up the argument for inclusion of both the change agent worldview and the contextual setting in which the change agent is involved.

The case study to develop an analytical model confirmed that change agents show a worldview profile rather than a specific worldview. It is this profile in combination with the context of the process that determines the impact of the CA on CS Integration. 


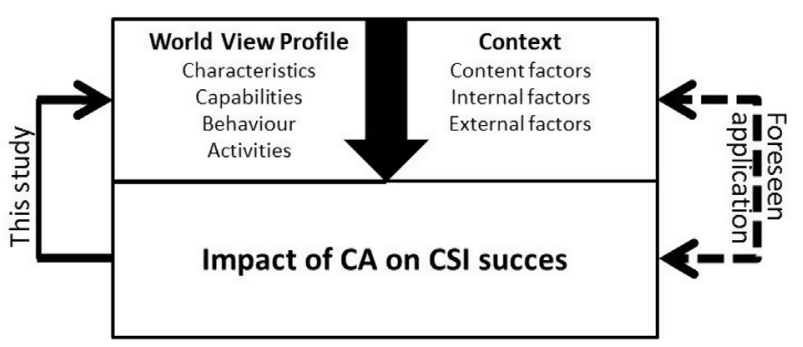

Fig. 2. Schematization of how the analytical model was used in this paper's retrospective case study and how it can be used for future retro-and prospective investigations of change agent impacts on CS integration.

After performing multiple case studies, it could be possible to project the impact of the CA on CS Integration and thus predict which combination of process context and CA worldview profile would be optimal for a specific case. Further, discussing patterns among the results supports a learning process based on which the organisation can make more conscious and informed future choices regarding who to appoint as change agent. Fig. 2 shows the application of the analytical model in our illustrative case study and the potential for further use in the near future.

\subsection{Limitations of the study and suggestions for future research}

Two aspects of the analytical model and its operationalization require further exploration and scientific debate. First, the chosen theory requires clear delineation of which elements correspond to which worldview, and clarification of the differences between these elements. Second, change agent selection should be discussed as potential change agents without formal positions are often not taken into consideration (see Boiral et al., 2014; Brown, 2012; Schein, 2014 who focus on change agents with formal leadership positions). These two topics for further research do not hamper the sense and necessity to start performing more case studies on the interplay between CA worldviews contextual factors and CS integration success and, in time, gather the information from these case studies and perform a meta-analysis to detect patterns in successful combinations of CA worldviews and specific contexts.

\section{References}

Armenakis, A.A., Bedeian, A.G., 1999. Organisational change: a review of theory and research in the 1990s. J. Manag. 25, 293-315.

Arrata, P., Despierre, A., Kumra, G., 2007. Building an effective change agent team. McKinsey Q. 1-5.

Azapagic, A., Perdan, S., 2005. An integrated sustainability decision-support framework Part I: problem structuring. Int. J. Sustain. Dev. World Ecol. 12, 98-111. https://doi.org/10.1080/13504500509469622.

Baron, C., Cayer, M., 2011. Fostering post-conventional consciousness in leaders: why and how? J. Manag. Dev. 30, 344-365. https://doi.org/10.1108 02621711111126828.

Baumgartner, R.J., 2009. Organisational culture and leadership: preconditions for the development of a sustainable corporation. Sustain. Dev. 17, 102-113. https:// doi.org/10.1002/sd.405.

Beck, D.E., Cowan, C., 1996. Spiral Dynamics: Mastering Values, Leadership and Change. John Wiley and Sons, New York.

Benn, S., Dunphy, D., Griffiths, A., 2006. Enabling change for corporate sustainability: an integrated perspective. Australas. J. Environ. Manag. 13, 156-165 https://doi.org/10.1080/14486563.2006.9725129.

Boiral, O., Cayer, M., Baron, C.M., 2009. The action logics of environmental leadership: a developmental perspective. J. Bus. Ethics 85, 479-499. https://doi.org/ 10.1007/s10551-008-9784-2.

Boiral, O., Baron, C., Gunnlaugson, O., 2014. Environmental leadership and consciousness development: a case study among Canadian SMEs. J. Bus. Ethics 123 363-383. https://doi.org/10.1007/s10551-013-1845-5.

Brown, B.C., 2011. An empirical study of sustainability leaders who hold postconventional consciousness. In: Ashridge International Research Conference on the Sustainability Challenge, pp. 1-13.
Brown, B.C., 2012. Leading complex change with post-conventional consciousness. J. Organ. Chang. Manag. 25, 560-575. https://doi.org/10.1108/ 09534811211239227.

Bryman, A., 2015. Social Research Methods. Oxford University Press.

Burgers, J.H., Jansen, J.J.P., Van den Bosch, F.A.J., Volberda, H.W., 2009. Structural differentiation and corporate venturing: the moderating role of formal and informal integration mechanisms. J. Bus. Ventur. 24, 206-220. https://doi.org/ 10.1016/j.jbusvent.2009.01.006.

Cook-Greuter, S.R., 2004. Making the case for a developmental perspective. Ind Commer. Train. 36, 275-281. https://doi.org/10.1108/00197850410563902.

Dam, Ynte K., Trijp, V., Hans, C.M.,V., 2011. Cognitive and motivational structure of sustainability. J. Econ. Psychol. 32, 726-741. https://doi.org/10.1016/j.joep.2011. 06.002 .

Denzel, D. van, 2016. Integrating Corporate Sustainability Strategy within a Dutch Public Agency. Utrecht University.

Divecha, S., Brown, B.C., 2013. Integral sustainability: correlating action logics with sustainability to provide new insights into the dynamics of change. J. Integr. Theory Pract. 8, 1-24.

Doppelt, B., 2009. Leading Change toward Sustainability: A Change-Management Guide for Business. Government and Civil Society. Greenleaf Publishing, Sheffield.

Dyllick, T., Hockerts, K., 2002. Beyond the business case for corporate sustainability. Bus. Strateg. Environ. 11, 130-141.

Eisenbach, R., Watson, K., Pillai, R., 1999. Transformational leadership in the context of organisational change. J. Organ. Chang. Manag. 12, 80-89. https://doi.org/10. $1108 / 09534819910263631$

Eisenhardt, K.M., 1989. Building theories from case study research. Acad. Manag. Rev. 14, 532-550. https://doi.org/10.2307/258557.

Eisenhardt, K.M., Graebner, M.E., 2007. Theory building from cases. Opportunities and challenges. Acad. Manag. J. 50, 25-32.

Epstein, M.J., Buhovac, A.R., 2010. Solving the sustainability implementation challenge. Organ. Dynam. 39, 306-315. https://doi.org/10.1016/j.orgdyn.2010.07. 003.

Fernandez, S., Rainey, H.G., 2006. Managing successful organisational change in the public sector. Publ. Adm. Rev. 66, 168-176. https://doi.org/10.1111/j.1540-6210. 2006.00570.x.

Gibson, C.B., Birkinshaw, J., 2004. The antecedents, consequences, and mediating role of organisational ambidexterity. Acad. Manag. J. 47, 209-226. https://doi. $\operatorname{org} / 10.2307 / 20159573$

Giddens, A., 1984. The Constitution of Society: Outline of the Theory of Structuration. Blackwell Publishing Ltd.

Hatch, M.J., Cunliffe, A.L., 2013. Organisation Theory, Modern, Symbolic, and Postmodern Perspectives. Oxford University Press.

Herron, C., Hicks, C., 2008. The transfer of selected lean manufacturing techniques from Japanese automotive manufacturing into general manufacturing (UK) through change agents. Robot. Comput. Integrated Manuf. 24, 524-531. https:// doi.org/10.1016/j.rcim.2007.07.014.

Hesselbarth, C., Schaltegger, S., 2014. Educating change agents for sustainability learnings from the first sustainability management master of business administration. J. Clean. Prod. 62, 24-36. https://doi.org/10.1016/j.jclepro.2013.03.042.

Hill, C., Jones, G., 2011. Essentials of Strategic Management. Cengage Learning, Boston, Massachusetts, USA.

Hunter, A.M.B., Lewis, N.M., Ritter-Gooder, P.K., 2011. Constructive developmental theory: an alternative approach to leadership. J. Am. Diet. Assoc. 111, 1804-1808. https://doi.org/10.1016/j.jada.2011.10.009.

Karlsson, C., Taylor, M., Taylor, A., 2010. Integrating new technology in established organisations: a mapping of integration mechanisms. Int. J. Oper. Prod. Manag. 30, 672-699. https://doi.org/10.1108/01443571011057290.

Kitzmueller, M., Shimshack, J., 2012. Economic perspectives on corporate social responsibility. J. Econ. Lit. 50, 51-84. https://doi.org/10.1257/jel.50.1.51.

Linnenluecke, M.K., Griffiths, A., 2010. Corporate sustainability and organisational culture. J. World Bus. 45, 357-366. https://doi.org/10.1016/j.jwb.2009.08.006.

Lawrence, P.R., Lorsch, J.W., 1967. Differentiation and integration in complex organizations. Adm. Sci. Q. 12 (1), 1-67.

Linnenluecke, M.K., Russell, S.V., Griffiths, A., 2009. Subcultures and sustainability practices: the impact on understanding corporate sustainability. Bus. Strateg. Environ. 18, 432-452. https://doi.org/10.1002/bse.609.

Loevinger, J., 1985. Revision of the sentence completion test for ego development. J. Personal. Soc. Psychol. 48, 420-427. https://doi.org/10.1177/ 014662167900300301.

Lozano, R., 2006. Incorporation and institutionalization of SD into universities: breaking through barriers to change. J. Clean. Prod. 14 (9-11), 787-796.

Lozano, R., 2012. Towards better embedding sustainability into companies' systems: an analysis of voluntary corporate initiatives. J. Clean. Prod. 25, 14-26. https:// doi.org/10.1016/j.jclepro.2011.11.060.

Lozano, R., Carpenter, A., Huisingh, D., 2015. A review of "theories of the firm" and their contributions to Corporate Sustainability. J. Clean. Prod. 106, 430-442. https://doi.org/10.1016/j.jclepro.2014.05.007.

Lynam, A., 2012. Navigating a geography of sustainability worldviews: a developmental map. J. Sustain. Educ. 3, 1-14.

Maas, K., Schaltegger, S., Crutzen, N., 2016. Integrating corporate sustainability analytical, management accounting, control, and reporting. J. Clean. Prod. 136, 237-248. https://doi.org/10.1016/j.jclepro.2016.05.008.

McCutcheon, D.M., Meredith, J.R., 1993. Conducting case study research in operations management. J. Oper. Manag. 11, 239-256. 
McEwen, C.A., Schmidt, J.D., 2007. Leadership And The Corporate Sustainability Challenge: Mindsets In Action. Avaston Consulting, Roswell. https://doi.org/10. 2139/ssrn. 1118071.

Miller, K., Serafeim, G., 2014. Chief sustainability officers: who are they and what do they do?. In: Leading Sustainable Change. Oxford University Press, pp. 1-22.

O'loughlin, D., 2011. The journey of personal and organisation development - with some maps for the trip. Australian Graduate School of Business E-Journal (AUGSB E-Journal) 4, 3-7.

O'Reilly, C.A., Tushman, M.L., 2013. Organisational ambidexterity: past, present, and future. Acad. Manag. Perspect. 27, 324-338. https://doi.org/10.5465/amp.2013. 0025.

Petersen, A.H., Boer, H., Gertsen, F., 2004. Learning in different modes: the interaction between incremental and radical change. Knowl. Process Manag. 11, $228-238$.

Rooke, D., Torbert, W.R., 2005. Seven Transformations of Leadership Seven Transformations of Leadership, 83. Havard Business Review, pp. 66-76. https://doi. org/10.1016/j.ajodo.2011.04.001.

Salzmann, O., Ionescu-Somers, A.M., Steger, U., 2005. The business case for corporate sustainability: literature review and research options. Eur. Manag. J. 23, 27-36. https://doi.org/10.1016/j.emj.2004.12.007.

Schein, S., 2014. The Ecological World Views and Post-conventional Action Logics of Global Sustainability Leaders. Doctoral dissertation. Fielding Graduate University, Santa Barbara, California.

Schein, S., 2015. A new psychology for sustainability leadership; the hidden power of ecological worldviews. J. Clean. Prod.140, 220. https://doi.org/https://doi.org/ 10.1016/j.jclepro.2015.11.045

Siebenhüner, B., Arnold, M., 2007. Organisational learning to manage sustainable development. Bus. Strateg. Environ. 16, 339-353. https://doi.org/10.1002/bse. 579.

Stelzer, D., Mellis, W., 1998. Success factors of organisational change in software process improvement. Software Process Improv. Pract. 4, 227-250. https://doi. org/10.1002/(SICI)1099-1670(199812)4:4<227::AID-SPIP106>3.0.CO;2-1.

Strudler, N.B., Gall, M.D., 1988. Successful change agent strategies for overcoming impediments to microcomputer implementation in the classroom. In: Paper Presented at the Annual Meeting of the American Educational Research Association (New Orleans, LA, April 5-9, 1988).

Stubbs, W., Cocklin, C., 2008. Conceptualizing a sustainability business model. Organ. Environ. 21, 103-127.

Uhl-Bien, M., Arena, M., 2018. Leadership for organisational adaptability: a theoretical synthesis and integrative framework. Leader. Q. 29, 89-104. https://doi. org/10.1016/j.leaqua.2017.12.009.

Van den Berg, J., 2016. Identifying Change Agents for Corporate Sustainability.
Corporate Sustainability Integration at RIVM. Utrecht University.

Van der Heijden, A., Cramer, J.M., Driessen, P.P.., 2012. Change agent sensemaking for sustainability in a multinational subsidiary. J. Organ. Chang. Manag. 25, 535-559. https://doi.org/10.1108/09534811211239218.

Van Marrewijk, M., 2003. Concepts and definitions of CSR and corporate sustainability: between agency and communion. J. Bus. Ethics 44, 95-105.

Van Opstal, M., Hugé, J., 2013. Knowledge for sustainable development: a worldviews perspective. Environ. Dev. Sustain. 15, 687-709. https://doi.org/10.1007/ s10668-012-9401-5.

Vincent, N.C., 2014. Evolving Consciousness in Leaders: Promoting Late-Stage Conventional and Post-conventional Development. Doctoral dissertation. University of Adelaide.

Vincent, N.C., Ward, L., Denson, L., 2013. Personality preferences and their relationship to ego development in Australian Leadership Program participants. J. Adult Dev. 20, 197-211.

Vincent, N.C. Ward, L., Denson, L., 2015. Promoting post-conventional conciousness in leaders: Australian community leadership programs. Leader. Q. 26, 238-253.

Visser, W., Crane, A., 2010. Corporate sustainability and the individual: understanding what drives sustainability professionals as change agents. SSRN Electron. J. https://doi.org/10.2139/ssrn.1559087.

Walker, J.H., Armenakis, A.A., Bernerth, J.B., 2007. Factors influencing organisationa change efforts. J. Organ. Chang. Manag. 20, 761-773. https://doi.org/10.1108 09534810710831000.

Weerts, K., Vermeulen, W., Witjes, S., 2018. On corporate sustainability integration: analysing corporate leaders' experiences and academic learnings from an organisational culture perspective. J. Clean. Prod. 203, 1201-1215. https://doi. org/10.1016/j.jclepro.2018.07.173.

Witjes, S., 2017. Leapfrogging through Retrospection: Ferreting Out Sustainability Integration within Organisations. Doctoral dissertation. Utrecht University.

Witjes, S., Vermeulen, W.J.V., Cramer, J.M., 2017a. Exploring corporate sustainability integration into business activities. Experiences from 18 small and medium sized enterprises in The Netherlands. J. Clean. Prod. 153, 528-538. https://doi. $\operatorname{org} / 10.1016 / j$.jclepro.2016.02.027.

Witjes, S., Vermeulen, WJ.V., Cramer, J.M. 2017b. Assessing Corporate Sustainability integration for corporate self-reflection. Resour. Conserv. Recycl. 127, 132-147. https://doi.org/10.1016/j.resconrec.2017.08.026.

Witjes, S., Cramer, J.M., Vermeulen, W.J.V., 2018. On corporate sustainability integration and the support of models. World Rev. Enterpren. Manag. Sustain. Dev. 14 (5), 581-607.

Yin, R.T., 1994. Case Study Research. Design and Methods, second ed. SAGE Publications Ltd. 